\title{
STRATEGI KOMUNIKASI PADA KEGIATAN MENTORING JEMAAH MASJID MANARUL ILMI (JMMI) ITS SURABAYA
}

\author{
Lutfi Alvian Widianto \\ STID Al-Hadid, Surabaya \\ lutfialvianwidianto@gmail.com
}

\begin{abstract}
Abstrak: Studi ini berdasarkan tesis yang berjudul "Strategi Komunikasi Pemasaran Sosial dalam Mencetak Kader Dakwah Kampus, Studi Kasus Kaderisasi Lembaga Dakwah Kampus ITS." Studi ini dilakukan dikarenakan terdapat sebuah Lembaga Dakwah Kampus (LDK) yang bernama Jemaah Masjid Manarul IImi (JMMI) yang telah berhasil mencetak mahasiswa yang memiliki kepribadian Islamiyah, daiyah, dan kepribadian pemimpin. Pada Studi ini dijelaskan secara rinci mengenai strategi komunikasi yang dilakukan oleh JMMI ITS dalam kegiatan mentoring untuk mencetak mahasiswa yang memiliki kepribadian Islamiyah, daiyah, dan kepribadian pemimpin. Acuan konsepnya menggunakan konsep komunikasi Anwar Arifin. Pendekatan riset dan analisinya deskriptif kualitatif, sedangkan data didapatkan dari hasil wawancara secara mendalam terhadap beberapa informan yang kredibel kapasitasnya dan didukung data dokumen, selain itu juga dilakukan triangulasi sumber. Hasil studi menunjukkan bahwa JMMI menggunakan strategi komunikasi sebagai berikut: (1) JMMI melakukan pengenalan terhadap komunikan, yaitu pengetahuan terhadap materi, bahasa kelompok yang didikuti, (2) JMMI melakukan penyusunan pesan, yaitu disesuaikan dengan bahasa yang dipahami komunikan, (3) JMMI melakukan pemilihan metode (4) JMMI melakukan pemilihan media, utamanya face to face, (5) JMMI memerankan komunikator, yaitu berakhlak baik, skill komunikasi baik, menjalin hubungan yang baik dengan komunikan.

Kata Kunci: strategi komunikasi, JMMI, mentoring
\end{abstract}

Abstract: This study is based on a thesis entitled "Strategi Komunikasi Pemasaran Sosial dalam Mencetak Kader Dakwah Kampus, Studi Kasus Kadersisasi Lembaga Dakwah Kampus ITS" This study was conducted because there is a Campus Da'wah Institute (LDK) named Jemaah Masjid Manarul IImi (JMMI) which has succeeded in producing students who have an Islamic personality, daiyah, and a leader personality. This study describes in detail the communication strategies carried outby JMMI ITS in mentoring activities to produce students who have Islamic, religious, and leadership personalities. Its conceptual matrix uses Anwar Arifin's communication concept. The approach of its research and analysis is qualitative descriptive, while its study data are obtained from the result of in-depth interview from some informants who have credibilities and from supporting documents. In addition, a source triangulation is conducted. The result of study indicates that JMMI uses communication strategies, as follow: 1) JMMI introduces the knowledge of material by using the group languages towards the communicants, 2) JMMI arranges messages; they are adjusted to the language understood by communicants, 3) JMMI selects a method, 4) JMMI selects a medium, primarily face to face one, 5) JMMI acts as a communicator having a good moral, skill of communication, and a good relationship with communicants.

Keywords: communication strategy, JMMI, mentoring 


\section{Pendahuluan}

Lembaga Dakwah Mahasiswa atau biasa disebut Lembaga Dakwah Kampus (LDK) merupakan salah satu organisasi kemahasiswaan intra kampus. Biasanya LDK selalu ada di setiap kampus atau perguruan tinggi (PT) di Indonesia. Kegiatan dakwah di kampus adalah sebuah tonggak dari kegiatan dakwah secara umum, dan menjadi kegiatan yang paling terasa pengaruhnya bagi masyarakat secara umum. ${ }^{1} \mathrm{Hal}$ itu bisa terjadi karena dakwah kampus memiliki beberapa keistimewaan. Diantara keistimewaan itu adalah sebagai berikut: (1) kampus adalah sebagai wadah berserikatnya generasi muda dalam waktu yang cukup lama; (2) mahasiswa adalah orang - orang terpilih di dalam sebuah masyarakat; (3) kampus merupakan sumber ilmu pengetahuan dan penelitian; (4) dakwah kampus merupakan tempat paling tepat untuk menciptakan kader dan pemimpin; (5) kampus merupakan tempat yang bebas dan terbuka untuk mengembangkan berbagai macam pemikiran; (6) mahasiswa memiliki banyak kesempatan untuk berinteraksi dengan kaum professional, kaum elit birokrasi, maupun kaum pelajar, mahasiswa, dan masyarakat umum); (7) mahasiswa kelak akan menjadi orang tua untuk generasi muda selanjutnya.

ITS atau Institut Teknologi Sepuluh November yang berada di Surabaya mempunyai sebuah Lembaga Dakwah Kampus yang bernama Jemaah Masjid Manarul IImi (JMMI). Lembaga Dakwah Kampus JMMI tersebut mempunyai suatu

\footnotetext{
1 Ahmad Atian, Menuju Kemenangan Dakwah Kampus, cet-1 (Solo: Era Intrmedia, 2010), 5.

2 JMMI ITS, Buku Panduan Bersama Lembaga Dakwah ITS (Surabaya: JMMI ITS, 2011), 4.
}

program kaderisasi dengan tujuan mencetak generasi muda kampus atau mahasiswa kampus yang memiliki kepribadian Islami, memiliki integritas tinggi dan dapat melanjutkan estafet dakwah di Kampus ITS. ${ }^{2}$ Dalam menyukseskan program tersebut, JMMI mempunyai kegiatan yang bernama pembinaan dan mentoring.

Para mahasiswa kampus ITS yang telah mengikuti kegiatan pembinaan dan mentoring, dalam dirinya terdapat perubahan yang positif. Yang mulanya mereka masih awam mengenai pengetahuan agama, berubah menjadi mahasiswa yang memiliki wawasan dan ilmu tentang ibadah, tauhid, adab pergaulan, akhlak yang baik, dan juga tentang sejarah-sejarah Rosul dan para sahabat. $^{3}$

Selain itu, kegiatan pembinaan dan mentoring juga dapat mengubah perilaku atau akhlak dari para mahasiswa menjadi lebih baik dari sebelumnya. Yang mulanya banyak mahasiswa yang tidak salat lima waktu menjadi salat lima waktu, yang mulanya salat lima waktu tidak berjamaah menjadi salat berjamaah, dan yang mulanya jarang atau bahkan tidak pernah membaca Alquran menjadi membaca Alquran setiap hari. Mengenai aturan dalam bergaul atau adab dalam bergaul, para mahasiswa yang mulanya berpacaran, melalui komunikasi persuasif yang dilakukan oleh para mentor, akhirnya mahasiswa tersebut tidak lagi pacaran, dan yang mulanya suka merokok berubah menjadi mahasiswa yang tidak suka merokok. ${ }^{4}$

\footnotetext{
3 Darori, Wawancara oleh Penulis, Masjid Manarul Ilmi Surabaya, 15 Mei 2017.

4 Ibid.
} 
Kegiatan Pembinaan dan Mentoring juga dapat membuat mahasiswa mempunyai kepribadian dai (syakhsiyah da'i). Awalnya, para mahasiswa tidak memiliki antusiasme sama sekali untuk berdakwah, namun setelah mengikuti kegiatan pembinaan dan mentoring, mahasiswa - mahasiswa tersebut menjadi memiliki antusiasme yang tinggi untuk dakwah, terutama dakwah di lingkungan ITS, baik itu berdakwah di JMMI ataupun di Lembaga Dakwah Jurusan (LDJ). Bukti dari meningkatnya semangat dakwah dari mahasiswa tersebut dapat dilihat dari jumlah total mahasiswa yang berbondong bondong mendaftarkan diri menjadi seorang dai atau biasa disebut mentor, atau aktivis dakwah di JMMI, pada tahun 2017 total terdapat 160 mahasiswa, pada periode sebelumnya JMMI sudah mempunyai 230 orang mentor. ${ }^{5}$ Dalam melaksanakan kegiatan dakwah, para mentor sangat totalitas dari sisi pengorbanan yang diberikan. Menurut penjelasan Rifki (salah seorang mentor), menjelaskan bahwa para mentor sering dan sudah sangat biasa mentraktir makan obyek dakwahnya dengan menggunakan uang saku yang dimiliki oleh para mentor. Tujuannya adalah agar para obyek dakwah, tidak dalam kondisi kelaparan dan merasa nyaman ketika kegiatan mentoring dilakukan. ${ }^{6}$ Tidak hanya itu pengorbanan yang dilakukan mentor, agar dapat membuat obyek dakwah selalu dapat mengikuti kegiatan mentoring, mentor - mentor selalu siap membantu obyek dakwah untuk menyelesaikan berbagai macam masalah yang dimiliki oleh obyek dakwah. Bahkan semisal obyek dakwah mengalami kesulitan atau kebingungan dalam menyelesaikan

\footnotetext{
${ }^{5}$ Ibid.

${ }^{6}$ Rifqi, Wawancara oleh Penulis, Masjid Manarul IImi Surabaya, 17 Mei 2017
}

tugas kuliah, mentor langsung membantu dengan menjelaskan konsepnya atau teorinya, tujuannya agar obyek dakwah tidak mengalami kesulitan lagi dalam menyelesaikan tugasnya. ${ }^{7}$

Kegiatan pembinaan dan mentoring juga mampu menjadikan mahasiswa memiliki kepribadian pemimpin atau dalam bahasa arabnya disebut syakhsiyah qiyadah. Hal itu terbukti dari kesuksesan para kader dakwah JMMI dalam memanajemen 3600 mahasiswa muslim ITS yang tersebar ke dalam 22 Jurusan. Para kader dakwah JMMI mampu menghidupkan kegiatan dakwah disetiap Lembaga Dakwah Jurusan atau LDJ yang berjumlah cukup banyak yakni 22 jurusan. Realitas tersebut menunjukkan bahwa kader dakwah atau mahasiswa mahasiswa JMMI memiliki kemampuan manajerial dan kepemimpinan yang baik. Tidak hanya itu, kader dakwah atau mahasiswa JMMI juga dapat mensukseskan program-program dakwah JMMI ITS. Contohnya seperti program Syiar, Kajian (tabligh), Isu, Kegiatan Keumatan, Media, Forum Syiar se-ITS. Dan untuk memberikan semangat untuk para kader dakwah atau mahasiswa JMMI tersebut, diadakan ajang pemberian reward. Reward tersebut akan diberikan kepada Ketua LDJ yang memiliki prestasi terbaik dalam melakukan kegiatan dakwah pada jurusan yang dikelolanya. ${ }^{8}$

Kesuksesan JMMI dalam mengubah mahasiswa yang awalnya biasa - biasa saja menjadi kader dakwah atau mahasiswa kampus ITS yang memiliki kepribadian Islamiyah, kepribadian daiyah, dan kepribadian pemimpin, tidak lepas dari

\footnotetext{
${ }^{7}$ lbid.

8 Darori, Wawancara oleh Penulis, Surabaya 10 Februari 2017
} 
strategi komunikasi yang dilakukan. Seperti penjelasan R. Wayne Pace, Brent D. Peterson, dan M. Dallas Burnet dalam Rusady Ruslan yang mengemukakan bahwa terdapat 4 tujuan strategi komunikasi, dan salah satu tujuannya adalah to motivate action atau memotivasi orang lain untuk melalukan perbuatan atau aksi tertentu. Morissan juga mengemukakan bahwa salah satu tujuan dari strategi komunikasi ialah membuat khalayak terdorong untuk mengambil sikap tertentu atau melakukan perbuatan tertentu. ${ }^{9}$ Dari penjelasan di atas dapat diketahui bahwa dalam membuat mahasiswa yang mulanya cenderung awam soal masalah agama, tidak ingin melakukan dakwah, dan tidak memiliki kepribadian kepemimpinan kemudian dirubah menjadi mahasiswa yang memiliki kepribadian Islamiyah, memiliki syakhsiyah da'i, dan memiliki syakhsiyah qiyadah, tentunya melalui sebuah proses strategi komunikasi yang tepat. Berdasarkan penjabaran di atas, artikel ini akan mengungkap dan mendeskripsikan strategi komunikasi yang dilakukan oleh JMMI dalam kegiatan mentoring, sehingga dapat menghasilkan kader dakwah atau mahasiswa yang memiliki kepribadian Islamiyah, karakter daiyah, dan syakhsiyah qiyadah.

\section{Strategi Komunikasi}

Strategi merupakan sebuah rencana cermat mengenai suatu kegiatan untuk mencapai suatu sasaran atau tujuan. Sasaran atau

\footnotetext{
9 Morissan, Manajemen Public Realitions: Strategi Menjadi Humas Profesional (Jakarta: Kencana, 2008), 187.

10 Rafi'udin dan Maman Abdul Djaliel, Prinsip dan Strategi Dakwah (Bandung: CV. Pustaka Setia, 1997), 77.

${ }^{11}$ Deddy Mulyana, Ilmu Komunikasi Suatu Pengantar (Bandung: PT Remaja Rosdakarya, 2002), 62.
}

tujuan akan sulit dicapai tanpa adanya sebuah strategi, hal tersebut disebabkan pada dasarnya berbagai macam kegiatan atau perbuatan tidak dapat terlepas dari sebuah strategi, termasuk dalam rangka manggapai suatu tujuan komunikasi, tentunya dibutuhkan strategi. ${ }^{10}$ Deddy Mulyana menjelaskan bahwa komunikasi merupakan proses suatu ide dipindahkan atau dikirimkan dari komunikator kepada suatu komunikan, dengan tujuan agar perilaku atau tingkah laku mereka berubah. ${ }^{11}$ Lasswell mengungkapkan pengertian komunikasi dalam bentuk penjelasan seperti ini: ${ }^{12}$ Who, Says what, In which channel, To whom, With what effect. Berdasarkan uraian di atas dapat disimpulkan strategi komunikasi merupakan suatu kegiatan terkonsep yang dilakukan agar dapat menggapai sebuah tujuan komunikasi.

Arifin menjelaskan bahwa dalam merumuskan sebuah strategi komunikasi terdapat lima pekara yang harus difokuskan, yaitu: ${ }^{13}$ mengenal khalayak (komunikan), merumuskan pesan, menentukan media komunikasi yang digunakan, menentukan metode komunikasi yang digunakan, menentukan komunikator.

\section{Mengenal Khalayak}

Hal pertama yang perlu diperhatikan dalam merumuskan strategi komunikasi adalah mengenali khalayak atau komunikan. Komunikan merupakan pihak yang menjadi

\footnotetext{
12 J Fiske, Cultural and Communication Studies: Sebuah Pengantar Paling Komprehensif, dierjemahkan Yosal Iriantara dan Idi Subandy Ibrahim, (Yogyakarta: Jalasutera, 2004), 46.

13 Anwar Arifin, Strategi Komunikasi: Sebuah Pengantar Rin gkas (Bandung: Armico, 1984), 59.
} 
obyek pesan yang dikirimkan oleh komunikator. ${ }^{14}$ Khalayak atau komunikan adalah sesuatu yang aktif, maksudnya aktif adalah mereka dapat menentukan untuk mengikuti ataupun menolak keinginan dari komunikator. Oleh sebab itu, komunikator wajib mengenali khalayaknya terlebih dahulu sebelum komunikasi dilakukan. Yang harus dikenali oleh seorang komunikator dari khalayaknya adalah pengalaman dan juga kerangka referensinya.

Anwar Arifin menjelaskan, seorang komunikator harus mengetahui 3 hal dari khalayaknya, 15 pertama, karakter kepribadian dan kondisi fisik dari khalayak, yang terdiri dari: (1) pengetahuan khalayak mengenai topik pembahasan atau topik persoalan. Sebelum melakukan komunikasi komunikator harusnya melakukan proses mencari data tentang tingkat pengetahuan komunikan mengenai topik yang akan dibahas. Dengan mengetahui data tersebut, komunikator akan dapat memberikan pesan yang sesuai dengan tingkat pengetahuan komunikan. (2) kemampuan komunikan untuk menerima pesan melalui media yang digunakan. Komunikator diharuskan juga mengetahui media yang biasanya digunakan atau yang disukai oleh komunikan. Hal tersebut berfungsi agar tepat dalam menentukan media komunikasinya; (3) perbendaharaan katakata komunikan. Komunikator harus mengetahui perbendaharaan kata-kata dari komunikan, agar nantinya ketika berkomunikasi kata-kata yang dikeluarkan oleh komunikator mudah dipahami komunikan.

\footnotetext{
14 Hafied Cangara, Perencanaan Dan Strategi Komunikasi. (Jakarta: Rajawali Pers, 2013), 37.

${ }^{15}$ Arifin, Strategi Komunikasi., 60.

${ }^{16}$ Ibid., 61.
}

Kedua, kelompok atau masyarakat yang melingkupi komunikan. Setiap kelompok atau masyarakat pasti memiliki nilai - nilai atau norma. Semua orang pasti ingin mendapatkan keseimbangan antara kepentingan pribadi dengan kepentingan kelompoknya. Semua orang pasti berusaha seoptimal mungkin untuk mempertahankan eksistensi dirinya dalam suatu kelompok.

Hubungan seseorang akan sangat erat dengan kelompok yang diikutinya bila orang tersebut tradisional. ${ }^{16}$ Oleh sebab itu, agar dapat mencapai sebuah tujuan komunikasi, seorang komunikator harus mengetahui kelompok yang yang diikuti oleh komunikan.

Ketiga, situasi dan kondisi dari komunikan. Situasi merupakan situasi yang melingkupi saat komunikan mendapatkan pesan dari komunikator. ${ }^{17}$ Situasi dibedakan menjadi 2 jenis yaitu situasi yang dapat diprediksi sebelum komunikasi terjadi dan situasi yang tidak dapat diprediksi. Contoh situasi yang bisa diprediksi adalah ketika ada seseorang yang ingin berceramah di sebuah pasar, orang tersebut bisa memprediksi kira - kira bagaimana situasi di pasar, yakni rame, banyak orang dll. Sehingga orang tersebut bisa menyiapkan diri untuk menghadapi situasi tersebut, mungkin dengan menggunakan media microphone dan memberikan volume suara yang lebih keras agar tidak kalah dengan suara bising di pasar. Yang dimaksud dengan kondisi adalah state of personality komunikan, yakni kondisi fisik dan psikis dari komunikan disaat menerima pesan dari komunikator. ${ }^{18}$

\footnotetext{
17 Uchjana, Ilmu Komunikasi Teori dan Praktek. (Bandung : PT Remaja Rosdakarya, 2005), 36.

18 Ibid., 37
} 
Maksud kondisi fisik dari komunikan contohnya seperti kelaparan, kecapekan, atau sedang sakit. Sedangkan contoh dari kondisi psikis adalah seperti rasa kebahagiaan, sedihan, kecewa , jengkel, dan sebagainya. Sebuah komunikasi tidak akan efektif bila seorang komunikan dalam kondisi psikologi yang buruk.

\section{Menyusun Pesan}

Dalam satu waktu, sebenarnya komunikan dapat menerima bermacam - macam pesan dari berbagai sumber. Oleh sebab itu proses menyusun pesan perlu dilakukan dengan sungguh - sungguh, tujuannya agar pesan pesan dari sumber lain tidak lebih menarik ketimbang pesan yang disampaikan oleh komunikator. Berhubungan dengan keterangan di atas, Wilbur Scrhamm (1955), dalam Arifin $^{19}$ menjelaskan terdapat 4 syarat yang perlu untuk dipenuhi, tujuannya agar pesan dapat sukses, yakni: (a) pesan harus dibuat dengan proses perencanaan yang baik dan juga harus disampaikan dengan baik agar dapat menarik perhatian komunikan; (b) pesan harus menggunakan tanda - tanda atau simbol - simbol yang telah disesuaikan dengan kerangka referensi dari komunikan; (c) pesan harus membangkitkan kebutuhan komunikan dan menyediakan solusi atau pemenuhan kebutuhan tersebut; (d) pesan harus dapat menjawab kelompok dimana komunikan berada.

Komunikan akan tertarik terhadap suatu pesan bila pesan tersebut dapat menyelesaikan masalah dan mampu memenuhi kebutuhan yang dimiiki oleh komunikan. ${ }^{20}$ Oleh sebab itu, agar pesan menarik bagi seorang komunikan, maka

${ }^{19}$ Arifin, Strategi Komunikasi., 68 - 69.

20 Ibid., 69. pesan tersebut perlu disesuaikan dengan permasalahan dan kebutuhan dari komunikan. Selain itu, menurut Wilbur Schramm sebuah pesan dapat menarik bagi komunikan ketika pesan tersebut mudah diperoleh (availability) dan contras (kontras). Kedua hal tersebut menyangkut penggunaan simbol - simbol atau tandatanda komunikasi dan penggunaan media komunikasinya. ${ }^{21}$ Yang dimaksud dengan pesan yang availability adalah pesan yang disampaikan oleh komunikator mudah didapatkan tanpa perlu menyita usaha yang banyak. Pesan yang kontras juga akan membuat pesan tersebut menjadi lebih dominan dan mencolok ketimbang pesan lainnya, sehingga akan membuat pesan tersebut lebih menarik bagi komunikan.

Selain pesan yang baik adalah pesan yang sesuai dengan kebutuhan komunikan. Selanjutnya, sebuah pesan juga harus dikemas dengan menggunakan tanda-tanda atau simbol - simbol yang sesuai dengan kerangka referensi komunikan. Atau bisa juga dijelaskan bahwa sebuah pesan harus dikemas ke dalam simbol - simbol bahasa yang diketahui atau yang dapat dipahami oleh komunikan. Berdasarkan penjelasan di atas mengenai syarat-syarat pesan yang baik, sebenarnya terdapat inti sari agar sebuah pesan dapat berhasil. Inti sarinya bahwa pesan harus mampu memenuhi atau sesuai dengan kebutuhan komunikan. Kebutuhan komunikan biasanya juga disebut personal needs dan social needs.

\section{Penetapan Metode}

Untuk mencapai sebuah tujuan komunikasi, tidak cukup hanya bermodal pesan yang sesuai dengan kondisi komunikan, tetapi

${ }^{21}$ Ibid., 70. 
juga diperlukan sebuah metode komunikasi untuk menyampaikan pesan kepada komunikan. Istilah metodologi secara etimologi berasal dari bahasa Yunani "metodos" yang yang memiliki arti sebuah cara atau jalan dan "logos" berarti ilmu22. Sehingga dari penjelasan tersebut dapat dijelaskan bahwa metode merupakan sebuah cara yang harus dilakukan untuk mencapai suatu tujuan dengan efektif dan efisien. Maksud dari efisien adalah antara biaya, waktu dan tenaga yang dikeluarkan untuk mencapai tujuan seminim mungkin. Sedangkan efektif berarti suatu yang berhubungan dengan pencapaian suatu hasil. ${ }^{23}$

Pada dasarnya dalam komunikasi metode dapat dibedakan menjadi 2 aspek, ${ }^{24}$ pertama, metode berdasarkan cara pelaksanaannya, yaitu: (a) redudancy (repetition). Maksud dari redudancy adalah memengaruhi komunikan dengan cara mengulang-ulang pesan yang disampaikan kepada komunikan. Dengan metode ini, akan membuat komunikan akan semakin perhatian terhadap pesan yang disampaikan, dan akan membuat komunikan lebih ingat terhadap pesan tersebut. Sebuah pesan yang menggunakan metode redudancy akan membuat sebuah pesan menjadi lebih kontras ketimbang pesan lainnya, sehingga membuat pesan tersebut lebih menarik perhatian komunikan. Meskipun metode tersebut memiliki manfaat yang besar, namun seorang komunikator tetap harus mempertimbangkan variasi-variasi redudancy agar tidak membosankan dalam memberikan pengulangan pesannya. Hal lainnya yang harus diperhatikan

${ }^{22}$ Asmuni Syukir, Dasar-Dasar Strategi Dakwah Islam (Surabaya: Al-Ikhlas, 1983), 99. komunikator adalah jumlah pengulangan yang dilakukan tidak boleh terlalu banyak, sebab bila terlalu banyak akan membuat komunikan menjadi bingung.

(b) canalizing. Merubah sikap komunikan bukan hal yang mudah. Agar dapat mengubah sikap komunikan, seorang komunikator harus mencari tahu kerangka referensi dari komunikan sehingga harapannya akan dapat memberikan pesan yang sesuai dengan kerangka referensi komunikan tersebut. Metode canalizing adalah sebuah metode merubah komunikan dimulai dari kondisi awal komunikan (start where the audience), kemudian sedikit demi sedikit komunikan tersebut dirubah sesuai harapan komunikator. Sehingga dalam menerapkan metode ini, seorang komunikator harus mencari tahu kerangka referensi dari komunikannya terlebih dahulu, setelah itu komunikator berkomunikasi dengan komunikan sesuai dengan kerangka referensinya. Tujuan dari metode ini adalah agar komunikan tidak defence. Setelah komunikan nyaman dan tidak defence, selanjutnya sedikit demi sedikit komunnikan dirubah menuju ke arah yang sesuai harapan komunikator. Canalizing juga dapat dilakukan dengan mengetahui pengaruh kelompok terhadap komunikan. Pada awal - awal komunikasi penyampaian pesan dilakukan sesuai dengan nilai-nilai kelompok yang dianut oleh komunikan, kemudian setelah itu menuju ke arah tujuan komunikator.

Kedua, menurut bentuk isinya, yaitu (a) Informative. Maksud dari informative adalah suatu bentuk pesan yang memiliki tujuan memberikan suatu informasi,

23 Ibid., 99.

${ }^{24}$ Arifin, Strategi Komunikasi., $73-78$. 
memberikan suatu pengetahuan atau wawasan kepada komunikan. Metode tersebut memberikan data berupa fakta atau pendapat yang benar - benar terjadi; (b) persuasive. Maksud dari persuasive adalah sebuah bentuk pesan yang memengaruhi khalayak dengan cara membujuk komunikan; (c) educative, adalah sebuah bentuk pesan yang mendidik komunikan, maksudnya adalah memberi suatu ide, pemikiran, kepada komunikan berdasarkan fakta, pendapat ataupun pengalaman yang kebenarannya dapat dipertanggungjawabkan, dan disusun dengan kesengajaan, keteraturan dan terencana dengan tujuan memengaruhi dan mengubah perilaku komunikan sesuai dengan harapan komunikator; (d) coersive, adalah bentuk pesan yang memengaruhi khalayak untuk melakukan sesuatu dengan cara paksaan atau kekerasan. Isi pesannya biasanya terdapat ancaman. Metode ini biasanya digunakan di dalam peraturanperaturan atau untuk mengintimidasi.

\section{Pemilihan Media}

Media adalah sebuah alat yang berfungsi sebagai perantara untuk menyampaikan pesan dari sumber kepada penerima pesan. Salah satu media komunikasi adalah media massa, contohnya seperti koran, majalah, radio, televisi, dan internet dsb. Selain itu media juga bisa berupa saluran contohnya kelompok arisan, kelompok pengajian, organisasi masyarakat, rumah ibadah, pesta rakyat, panggung kesenian, serta media alternatif lain seperti poster, brosur, buku, spanduk, dan sebagainya. ${ }^{25}$ Bila seorang komunikator hendak menggunakan media komunikasi tertentu, hendaknya dilakukan analisa dengan baik terlebih dahulu agar

${ }^{25}$ Cangara, Perencanan dan Strategi Komunikasi., 37.

${ }^{26}$ Uchjana, IImu Komunikasi., 37. media tersebut dapat menjadi katalisator yang baik. Menurut Effendy, ${ }^{26}$ pemilihan media komunikasi dipengaruhi oleh komunikan yang ditarget, efek yang diinginkan komunikator dan pesan yang akan disampaikan kepada komunikan.

Unesco menjelaskan bahwa dalam memilih media komunikasi, ada beberapa hal yang sangat perlu diperhatian, antara lain, ${ }^{27}$ (a) sumber daya komunikasi yang tersedia di suatu tempat; (b) kepemilikan media oleh komunikan; (c) kemampuan media dalam menjangkau komunikan.

\section{Peran Komunikator}

Komunikator memiliki pengaruh yang sangat besar dalam komunikasi. Alasannya adalah dikarenakan komunikator adalah orang yang menyampaikan pesan kepada komunikan. Oleh sebab itu, bila suatu komunikasi gagal atau tidak mencapai tujuan, maka yang harus disalahkan adalah komunikator. Hal tersebut juga disebabkan komunikatorlah yang melakukan proses penyusunan pesan, yang memilih media, dan yang menyampaikan pesan kepada komunikan.

Arifin menjelaskan bahwa seorang komunikator harus memiliki credibility atau dapat dipercaya oleh komunikan. Menurut Arifin, credibility atau kepercayaan dapat tercipta dari beberapa hal di bawah ini, ${ }^{28}$ pertama, kompetensi atau kemampuan dari komunikator soal topik pesan yang disampaikan. Contohnya, bila seorang komunikator ingin membicarakan mengenai topik soal Islam, maka seorang komunikator harusnya memiliki wawasan atau pengetahuan yang baik mengenai Islam. Kedua, kemampuan dalam menyajikan

\footnotetext{
${ }^{27}$ Cangara, Perencanan dan Strategi Komunikasi, 147.

${ }^{28}$ Arifin, Strategi Komunikasi., 91.
} 
pesan. Yang dimaksud dengan kemampuan menyajikan pesan adalah kemampuan dalam menyusun pesan dan juga cara menyampaikan pesannya. Kemampuan menyusun pesan diantaranya adalah menentukan tema atau topik pembahasan, gagasan penjelas dan diksi. Kemudian cara penyampaian juga harus baik. Kemampuan dalam menyampaikan pesan yang baik, akan mampu menciptakan kepercayaan komunikator di mata komunikan. Contohnya seperti Barrack Obama, dengan kemampuan komunikasinya yang sangat baik, hal itu akhirnya mampu membuat komunikan memberikan kepercayaannya terhadap Obama.

Ketiga, memiliki akhlak atau budi pekerti yang baik. Hal tersebut sesuai dengan yang penjelasan Aristoteles pernah menjelaskan bahwa seorang komunikator diharuskan memiliki etos. Etos adalah aspek kepribadian dari seorang komunikator sehingga mengakibatkan aucapanucapannya akan dipercaya oleh komunikan. Contoh aspek kepribadian komunikator yang baik adalah selalu jujur dan tidak pernah berbohong, selalu berusaha menjadi orang yang berwibawa dan baik hati. Keempat, memiliki hubungan yang baik dengan komunikan. Seorang komunikator bila ingin dipercaya komunikannya, harus menjalin kedekatan hubungan yang baik dahulu dengan komunikannya. Keakraban biasanya akan terjadi bila diantara komunikan dan komunikator hidup bersama, bekerja bersama atau bermain bersama. Intinya adalah kebersamaan. Keakraban juga dapat terjadi bila antara komunikator dan komunikan terdapat persamaan nilai-nilai, pendidikan, status sosial, dan sebagainya. ${ }^{29}$

\section{Metodologi}

Studi ini masuk ke dalam jenis penelitian deskriptif dengan pendekatan kualitatif. Pada studi ini akan dideskripsikan secara mendalam mengenai strategi komunikasi yang dilakukan oleh JMMI dalam kegiatan mentoring dakwah kampus atau kader dakwah kampus. Data - data mengenai strategi komunikasi yang dilakukan oleh JMMI didapatkan dari hasil wawancara terhadap tiga orang informan yang dianggap mengetahui sepenuhnya tentang kegiatan mentoring, dan mengetahui strategi komunikasi JMMI pada saat melakukan kegiatan mentoring tersebut. Dan informasi tersebut dapat dipastikan akurat, jelas, dan terpercaya. Informan dalam studi ini dibagi menjadi beberapa kriteria, yaitu: key Informan dan Informan.

Tabel.1 - Key Informan dan Informan

\begin{tabular}{c|l|l}
\hline \multicolumn{1}{c|}{ Kategori } & \multicolumn{1}{|c}{ Nama dan Jabatan } & \multicolumn{1}{c}{ Alasan Pemilihan } \\
\hline Key Informan & $\begin{array}{l}\text { Ketua Program Pembinaan } \\
\text { dan Mentoring. }\end{array}$ & $\begin{array}{l}\text { Merupakan pihak JMMI yang paling mengerti } \\
\text { mengenai strategi komunikasi JMMI dalam } \\
\text { rangka menciptakan kader dakwah atau aktivis } \\
\text { dakwah. Selain itu beliau juga merupakan pihak } \\
\end{array}$ \\
& $\begin{array}{l}\text { yang dianggap memiliki wewenang dalam } \\
\text { memberikan data-data yang terkait dengan } \\
\text { strategi komunikasi JMMI dalam mencetak } \\
\text { aktivis dakwah kampus. }\end{array}$ \\
\hline
\end{tabular}

${ }^{29}$ Ibid., 91. 


\begin{tabular}{l|l|l}
\hline Informan & Ketua Program Kaderisasi & $\begin{array}{l}\text { Dikarenakan beliau adalah orang yang ikut } \\
\text { berperan dalam melaksanakan program } \\
\text { kaderisasi, sehingga juga mengetahui strategi } \\
\text { komunikasi JMMI dalam rangka mencetak } \\
\text { kader dakwah di kampus ITS. }\end{array}$ \\
Informan & $\begin{array}{l}\text { Mentor } \\
\text { Dikarenakan beliau adalah orang yang } \\
\text { melaksanakan strategi komunikasi dalam } \\
\text { rangka mencetak kader dakwah. }\end{array}$ \\
\hline
\end{tabular}

Metode pengumpulan data yang digunakan dalam studi ini adalah wawancara secara mendalam. Jenis wawancara yang dilakukan adalah wawancara semi struktur. Pada wawancara semi struktur, pewawancara mempunyai daftar pertanyaan tertulis tapi memungkinkan untuk menanyakan pertanyaan-pertanyaan secara bebas, yang terkait dengan permasalahan. Wawancara dan pengumpulan data sekunder dilakukan selama bulan Februari-Juni 2017 yang dilakukan secara langsung di Masjid Manarul IImi ITS Surabaya.

Analisis data menggunakan model Miles dan Huberman, yakni: (1) pengumpulan data, (2) reduksi data, (3) penyajian data, (4) penarikan kesimpulan. Teknik keabsahan data yang dilakukan adalah teknik triangulasi tepatnya triangulasi sumber, yaitu dengan cara membandingkan atau mengecek ulang derajat kepercayaan suatu informasi yang diperoleh dari sumber yang berbeda.

\section{Strategi Komunikasi Mentoring JMMI ITS}

\section{Tujuan}

Tujuan dari program Pembinaan dan Mentoring adalah mencetak kader dakwah dengan kepribadian Islam, memiliki integritas tinggi dan mampu melanjutkan tongkat estafet dakwah utamanya di kampus ITS. ${ }^{30}$ Ada tiga kepribadian yang hendak diciptakan oleh JMMI, yakni kader dakwah dengan memiliki kepribadian Islam atau syakhsiyah Islamiyah, kepribadian dai atau syakhsiyah daiyah, dan kepribadian pemimpin atau syakhsiyah qiyadah. ${ }^{31}$

Maksud dari kader dengan kepribadian Islam ialah kader yang memiliki akidah, akhlak, serta ibadah yang baik. Beberapa indikator untuk mengukur kepribadian Islami dari seorang kader dakwah adalah 1) dilihat apakah dia telah memiliki dan melakukan adab pergaulan yang baik (khususnya dengan lawan jenis), 2) yang kedua dilihat dari ibadah salat lima waktunya, 3) Apakah kader - kader tersebut sudah rutin membaca Alquran, dan sebagainya. ${ }^{32}$ Yang dimaksud dengan kader yang memiliki kepribadian dai adalah kader memiliki kemampuan, pengetahuan, dan

32 Darori, Wawancara oleh Penulis, Masjid Manarul Ilmi Surabaya, 15 Mei 2017.
30 JMMI ITS, Buku Panduan Bersama Lembaga Dakwah ITS (Surabaya: JMMI ITS, 2011),4.

31 Ibid., $17-18$. 
semangat untuk melaksanakan dakwah di lingkungan ITS. Kegiatan dakwah di JMMI bisa dibagi menjadi tiga yakni, 1) menjadi seorang mentor yang tugasnya adalah mengisi kegiatan mentoring, 2) menjadi seorang staf dakwah di JMMI, 3) menjadi staf dakwah di Lembaga Dakwah Jurusan atau LDJ.

Yang dimaksud dengan kader yang memiliki kepribadian pemimpin adalah seorang kader yang memiliki kemampuan manajemen dan kemampuan kepemimpinan yang baik. Kader - kader dengan kepribadian pemimpin tersebut nantinya diharapkan mampu menjadi kader yang memegang jabatan-jabatan strategis di JMMI dengan baik.

\section{Mengenal Komunikan}

Mentor - mentor JMMI ITS sebelum melakukan mentoring, selalu melakukan pengenalan komunikannya dahulu. Hal pertama yang harus dikenali dari komunikan adalah pengetahuan komunikan tentang topik pembahasan. JMMI mencari tahu pengetahuan yang dimiliki para mahasiswa yang sejumlah 3600 orang. Caranya mencari tahunya adalah dengan memberikan sebuah tes tulis kepada para mahasiswa mahasiswa baru tersebut. Tes tersebut berisi tentang pengetahuan-pengetahuan tentang Islamiyah seperti tauhid, akhlak, dan ibadah. ${ }^{33}$ Tujuan dari diberikannya tes tersebut yakni untuk mengetahui atau mengenali tingkat pengetahuan yang dimiliki oleh para mahasiswa baru tersebut, spesifiknya mengenai soal tauhid, akhlak dan ibadah. Setelah diketahui tingkat pengetahuan mahasiswa - mahasiswa tersebut, JMMI mengelompok - ngelompokkan para mahasiswa tersebut berdasarkan tingkat pengetahuan keislamannya. Semisal ada mahasiswa yang tingkat pengetahuan akhlak dan tauhid sudah cukup baik, maka mahasiswa mahasiswa tersebut akan dikumpulkan menjadi satu kelompok, begitu juga dengan tingkat pengetahuan yang lainnya.

Tujuan dari dikelompok - kelompokkannya mahasiswa berdasarkan tes tersebut adalah agar mentor mudah dalam melakukan mentoring. Dikarenakan bila mahasiswa yang menjadi obyek mentoring homogen atau memiliki kesamaan tingkat pengetahuan maka akan semakin bisa efektif komunikasinya.

Kedua, selain melakukan pengenalan terhadap tingkat pengetahuan komunikan, JMMI juga melakukan pemetaan kira - kira media komunikasi apa yang tepat untuk digunakan dalam proses mentoring. Direktur BPM, Darori menjelaskan bahwa para obyek mentoring cenderung lebih tertutup atau sungkan ketika mentor menggunakan media SMS atau chatting-an. Oleh karena menurut Darori lebih baik dalam berkomunikasi dengan mahasiswa menggunakan media langsung atau face to face. Menurut Darori, dengan face to face membuat komunikan menjadi tidak sungkan-sungkan dan terbuka ketika berdialog. ${ }^{34}$

Ketiga, sebelum melakukan mentoring JMMI juga berusaha mengetahui perbendaharaan kata atau tingkat pengetahuan bahasa dari komunikannya. Menurut salah satu mentor, Rifki menjelaskan bahwa seorang mentor dalam 
berkomunikasi dengan komunikan harus berusaha menggunakan bahasa yang sesuai dengan komunikannya, contohnya ketika komunikannya sering di warung kopi atau cangkrukan, maka harusnya mentor menggunakan bahasa-bahasa yang tidak kaku atau nonformal. ${ }^{35}$ Bila komunikannya secara pengetahuan akan agama cukup banyak, dulunya dia pernah ikut rohis sewaktu SMA maka mentor dalam berkomunikasi dengan dia harus menggunakan istilah-istilah yang teknis soal agama. $^{36}$

JMMI juga melakukan pengenalan berdasarkan kelompok yang melingkupi diri komunikan. Contohnya adalah JMMI melakukan pemetaan dengan melihat apakah komunikan ketika masih SMA mengikuti rohis atau tidak. JMMI bisa mengetahui hal tersebut dari kuisioner atau angket yang diberikan kepada para mahasiswa. Salah satu pertanyaan yang ada pada kuisioner tersebut adalah apakah dulunya ketika SMA sudah pernah mengikuti rohis ataukah tidak. ${ }^{37} \mathrm{JMMI}$ perlu mengetahui hal tersebut dikarenakan bila mahasiswa tersebut pernah aktif mengikuti rohis ketika SMA, apalagi semisal sudah pernah mengikuti mentoring, maka secara nilai-nilai sudah sesuai, tidak perlu adanya penyesuaian lagi.

Selain itu, JMMI juga mencari tahu organisasi yang pernah diikuti oleh komunikan, baik organisasi dakwah maupun organisasi nondakwah. JMMI mendapatkan Informasi tersebut dari hasil kuisioner yang diberikan kepada mahasiswa sebelum

35 Rifqi, Wawancara oleh Penulis, Masjid Manarul Ilmi Surabaya, 17 Mei 2017.

${ }^{36} \mathrm{lbid}$.

37 Ibid. mentoring. Informasi mengenai organisasi yang pernah diikuti komunikan tersebut berfungsi untuk mengetahui kecenderungan nilai-nilai yang dipegang oleh komunikan. Dengan diketahuinya organisasi dakwah yang pernah diikuti, maka akan diketahui kecenderungan aliran agama dari komunikan. Menurut Rifki kelompok aliran agama dari komunikan juga perlu diketahui. ${ }^{38}$ Tujuannya adalah untuk memudahkan mentor ketika proses mentoring dan agar komunikator tidak menabrak nilai-nilai atau norma-norma yang dimiliki para mahasiswa tersebut .${ }^{39}$ Setelah diketahui kelompok aliran agamanya, selanjutnya JMMI mengelompokkan mahasiswa - mahasiswa tersebut sesuai dengan kelompok agamanya, bahkan JMMI mencarikan mentor khusus yang tepat untuk mengisi mentoring terhadap mahasiswa yang memiliki kelompok aliran agama tertentu, tujuannya agar kegiatan mentoring tetap berjalan dengan baik. ${ }^{40}$

Sebelum masuk pada proses mentoring, para mentor juga selalu memetakan situasi dan kondisi dari komunikan terlebih dahulu. Para mentor JMMI harus peka terhadap kondisi dari komunikannya. Darori memberikan penjelasan, misalnya ada peserta ketika proses mentoring tiba - tiba merasa mengantuk berat karena kelelahan setelah aktivitas, maka kegiatan mentoring dicukupkan atau ditunda. ${ }^{41}$ Darori juga menjelaskan bahwa semisal waktu mentoring tiba-tiba diketahui bahwa komunikan sedang memiliki sebuah masalah, maka materi yang seharusnya

\footnotetext{
38 Ibid.

39 Ibid.

40 Ibid.

41 Darori, Wawancara oleh Penulis, Masjid Manarul Ilmi Surabaya, 15 Mei 2017.
} 
dibahas pada waktu mentoring diganti dengan membahas atau menyelesaikan masalah dari komunikan terlebih dahulu. Selain itu, Rifki juga menjelaskan, misalnya waktu mentoringnya malam hari yakni setelah salat magrib, dan kebetulan kondisi dari mahasiswa sedang kelaparan, akhirnya mentor mengajak mahasiswa tersebut makan malam dahulu dan mentor yang mentraktirnya. Sembari makan bersama, mahasiswa sambil diberi materi sedikitsedikit." $^{42}$

\section{Merumuskan Pesan}

Materi - materi yang disampaikan oleh mentor ketika kegiatan mentoring tidak boleh sembarangan, dikarenakan JMMI memiliki kurikulum materi yang jelas untuk mentoring. Kurikulum meteri tersebut diciptakan agar tujuan JMMI dalam mencetak kader berkepribadian Islamiyah, berkepribadian dai dan berkepribadian kepemimpinan dapat terwujud. Pada tahap kaderisasi satu, semua materi yang disampaikan oleh mentor kepada mahasiswa bertujuan untuk membentuk mahasiswa berkepribadian Islamiyah. Pada tahap kaderisasi satu, materinya fokus pada dasar-dasar kelslaman dari komunikan, dimulai dari membahas makna syahadat, ghozwul fikr, fikih taharah, fikih salat, adab bergaul birul walidain, dan membahas tentang sejarah-sejarah Rasul. ${ }^{43}$

Pada tahap kedua kaderisasi, materi yang disampaikan oleh mentor kepada mahasiswa bertujuan untuk membentuk mahasiswa berkepribadian daiyah dari mahasiswa. Oleh sebab itu pada tahap

\footnotetext{
42 Rifqi, Wawancara oleh Penulis, Masjid Manarul IImi Surabaya, 17 Mei 2017.

43 JMMI ITS, Buku Panduan., 19.

${ }^{44}$ Ibid., 19.
}

kedua kaderisasi, materinya cenderung membahas tentang dakwah seperti: fikih dakwah, dakwah kampus, mujahadah dalam dakwah, marketing dakwah, public speaking, amal jama'i atau dakwah berorganisasi dan lain - lain. ${ }^{44}$ Pada tahap ketiga kaderisasi, materi yang disampaikan oleh mentor kepada mahasiswa bertujuan membentuk mahasiswa berkepribadian pemimpin. Dikarenakan tujuannya adalah untuk membentuk mahasiswa berkepribadian pemimpin, maka materi materi mentoringnya bertemakan permasalahan - permasalahan yang akan dihadapi oleh seorang pemimpin, dan memberikan bekal ketika menjadi seorang pemimpin. Materi-materi yang diberikan antara lain: (a) Sirah Khilafah Islamiah, (b) Studi Pemikiran dan Gerakan Islam, (c) Fikih Daulah, (d)Takwinul Ummah, (e) Manajemen Organisasi, (f) Leadership, (g) Komunikasi Politik, dan sebagainya. ${ }^{45}$

Pada kenyataannya di lapangan, khusus untuk kaderisasi pertama, diperbolehkan untuk menyampaikan materi-materi diluar kurikulum yang sudah ditetapkan. Syaratnya, materi tersebut telah memperoleh izin atau telah disetujui oleh Lembaga Dakwah Jurusan atau LDJ. ${ }^{46}$ Materi di luar kurikulum biasanya diberikan ketika mahasiswa sedang berada pada kondisi atau situasi khusus, contohnya semisal pada suatu waktu, kondisi mahasiswa sedang down, akhirnya mentor tidak membahas materi seharusnya yang sesuai dengan kurikulum melainkan membahas topik yang sesuai dengan masalah yang sedang dihadapi mahasiswa tersebut. ${ }^{47}$ Selain itu,

\footnotetext{
45 Ibid., 19.

46 Ibid., 17.

47 Darori, Wawancara oleh Penulis, 15 Mei 2017.
} 
seorang mentor juga perlu memiliki kemampuan dalam mengemas materi dakwah agar sesuai dengan kondisi mahasiswa. Contohnya semisal ketika komunikannya hobinya cangkrukan di warung kopi, maka cara seorang mentor dalam menyampaikan ayat-ayat Alquran maupun Hadis diletakkan di bagian belakang, bukan diawal, disebabkan apabila diletakkan diawal, dikhawatirkan mahasiswa tidak akan menyukainya. Sedangkan, bila mahasiswa yang dihadapi adalah orang yang religius maka menggunakan ayat-ayat Alquran maupun Hadis di awal tidak menjadi masalah. ${ }^{48}$

Seorang mentor JMMI juga harus mampu memilih bahasa atau diksi yang sesuai dengan keadaan komunikannya. Jadi, semisal ada komunikan yang hobinya cangkrukan maka bahasa atau diksi yang dipilih adalah bahasa yang non formal. Namun bila pengetahuan komunikan banyak, maka mentor harus menggunakan istilah-istilah teknis. ${ }^{49}$ Yang tidak kalah penting adalah seorang mentor harus mampu mendesain pesan agar pesan tersebut disenangi oleh komunikan. Contohnya ketika mentor menjelaskan materi tentang sikap seorang anak, bahwa sikap anak kepada orang tua harus A, B, C. Semisal ketika itu, mentor melihat kondisi komunikannya ternyata kurang suka karena dikira menghakimi komunikan, maka mentor harus mengganti dengan memberikan kisah pengalaman mentor terhadap orang tua agar tidak ada kesan menghakimi komunikan. ${ }^{50}$

48 Rifki, Wawancara oleh Penulis, 17 Mei 2017.

${ }^{49}$ Ibid.

$50 \mathrm{lbid}$.

\section{Memilih Media}

Mentor - mentor JMMI secara umum lebih sering menggunakan media face to face ketika melakukan kegiatan mentoring. Alasan para mentor memilih menggunakan media face to face adalah agar komunikan semakin terbuka tidak menutup-nutupi. Penjelasan di atas sesuai dengan ketarangan dari Darori, "Jarang kalau sampai telepon-telepon begitu, lebih baik langsung ketemu, ketika ketemu gitu kan, semisal dia gak hadir mentoring itu kita cari, kita tanya kenapa dek koq gak ikut mentoring, oh gak apa mas, kadang dia nutup-nutupi, akhirnya nanti membuka. ${ }^{51 "}$

Selain menggunakan media langsung, para mentor JMMI biasanya juga menggunakan media sosial berupa grup Whats App. Media grup Whats App tersebut digunakan oleh mentor untuk memberikan pengetahuan pengetahuan ringan di luar materi yang sudah terkurikulum, contohnya seperti berita-berita atau link-link website. ${ }^{52}$

\section{Memilih Metode}

Agar sukses dalam menciptakan mahasiswa berkepribadian Islami, contohnya dalam soal ibadah, maka tidak cukup hanya dengan sekali pertemuan saja. Untuk dapat membuat mahasiswa yang memiliki kepribadian islami khususnya ibadah, mentor JMMI melakukan proses untuk merubahnya secara terus menerus sampai perubahan tersebut terwujud. Setiap minggu, para mentor selalu mengingatkan mahasiswanya soal ibadahnya, termasuk menanyakan tentang perkembangan atau perubahan soal ibadah yang sudah

\footnotetext{
51 Darori, Wawancara oleh Penulis, Masjid Manarul IImi Surabaya, 15 Mei 2017.

52 Rifqi, Wawancara oleh Penulis, Masjid Manarul IImi Surabaya, 17 Mei 2017.
} 
dilakukan mahasiswa. Hal tersebut sejalan dengan keterangan dari Rifki, "Dalam merubah perilaku terutama akhlak dari mente memang dilakukan berulang-ulang, setiap minggu ditanyakan perkembangannya, semisal awalnya salat, ditanyain terus dibuatkan laporan setiap minggu, bila ada masalah atau problem diberi motivasi. ${ }^{\prime 53}$

Apabila ketika proses mentoring seorang komunikan memiliki pandangan yang berbeda atau bahkan bertentangan dengan pandangan dari mentor, maka mentor JMMI berusaha tidak akan menyentuh sama sekali sisi yang bertentangan tersebut, namun seorang komunikator berusaha mengikuti apa yang disepakati oleh komunikan terlebih dahulu. Mentor JMMI berusaha selalu menghindari pertentangan dengan komunikan dan selalu berusaha menunjukkan kebaikan atau persamaan dengan komunikan dahulu, sampai akhirnya mahasiswa menilai bahwa mentor merupakan sosok orang yang baik. Setelah mahasiswa atau komunikan menfigurkan sang mentor, langkah selanjutnya seorang mentor sudah bisa mengubah konsep atau pandangan dari komunikan secara pelan pelan dan bertahap. Hal tersebut sejalan dengan keterangan dari Rifki, "Apabila ingin merubah komunikan yang memiliki perbedaan itu harus dilakukan secara perlahan. Di awal yang paling penting adalah menuruti dahulu apa yang dia suka, dia suka makan semisal kita berikan makan, kita turuti dahulu kesukaan dia, bahkan ketika dia semisal memiliki pendapat yang berbeda, mentor harus berusaha menahan dahulu jangan sampai memberikan jawaban yang negatif, ditahan dahulu,

$53 \mathrm{lbid}$.

54 lbid. sampai nantinya ketika sudah akrab dan semakin dekat mereka sudah nyaman, sudah menganggap kita adalah orang yang baik, sudah percaya terhadap kita, selanjutnya adalah baru sedikit demi sedikit merubahnya. ${ }^{154}$

\section{Peran Komunikator}

Ada beberapa karakter yang harus dimiliki oleh seorang mentor JMMI, salah satunya adalah karakter ruhiyah. Kekuatan ruhiyah akan lahir dari aktivitas ruhiyah yang dilakukan oleh seseorang mentor, salah satu aktivitas ruhiyah adalah ibadah ilahiah. Dengan seorang mentor beribadah, maka ruh mentor akan menjadi semakin kuat, hati dapat terkendali, dan akan selalu siap melakukan semua perintah Allah. Berikut ini adalah beberapa aktivitas ruhiyah yang harus dimiliki oleh mentor di JMMI : ${ }^{55}$ (a) beribadah dengan benar; (b) memelihara salat-salat wajib dan sunah; (c) membiasakan salat malam; (d) membaca Alquran secara kontinu; (e) menjaga wiridwirid dan zikir-zikir ma'tsurat; (f) senantiasa merendahkan diri terhadap Allah dengan cara berdoa; (g) dan selalu menjaga amalamal ibadah sunah lainnya.

Selain mentor harus memiliki karakter ruhiyah, mentor JMMI juga wajib memiliki sifat atau akhlak yang baik. Hal tersebut dikarenakan nantinya komunikan akan selalu memperhatikan sikap dan perbuatan dari mentor. Akhlak mulia yang harus dimiliki oleh setiap mentor JMMI sebagai berikut: $^{56}$ (a) rendah hati (tawadlu), menolak apapun hal itu bila memang hal tersebut bukan haknya, dan seorang mentor harus mendahulukan kepentingan orang lain (itsar); (b) memiliki sikap toleran dan

\footnotetext{
55 JMMI ITS, Buku Panduan. 13.

56 Ibid., 13.
} 
memiliki wawasan yang luas. Berdasarkan penjelasan Darori, mentor JMMI juga harus memiliki sikap toleransi, seorang mentor harus berkenan menerima perbedaan pemikiran soal agama, tidak boleh bersifat keras terhadap sebuah perbedaan; ${ }^{57}$ (c) memberikan qudwah yang bijak pada orang lain; (d) bertanggung jawab dalam mengemban amanah.

Dalam bergaul dengan lawan jenis, seorang mentor JMMI diharuskan memiliki akhlak yang baik. Mentor JMMI dilarang berpacaran dengan alasan apapun. Selain pacaran, mentor JMMI juga tidak diperbolehkan merokok. Bila diketahui ada seorang mentor JMMI yang berpacaran atau merokok maka mentor tersebut diberikan sanksi yakni akan dicabut status mentornya. ${ }^{58}$

Menurut Darori, terdapat alasan mengapa seorang mentor tidak diperbolehkan merokok yakni dikarenakan merokok akan menyebabkan seorang mentor menjadi tidak produktif ketika melakukan dakwah, dan juga komunikan akan memiliki kesan yang kurang baik terhadap mentor tersebut..$^{59}$ Seorang mentor juga diharuskan memiliki pemikiran yang baik. Mentor harus memiliki pemikiran yang baik, dikarenakan bila pemikiran mentor tidak baik, dipastikan ketika berdakwah kepada komunikan akan menemui kendala-kendala. Sebab itu, seorang mentor harus memiliki karakter dalam hal pemikiran sebagai berikut: ${ }^{60}$ (a) mentor memiliki kematangan konsep mengenai persoalan dakwah. Seorang mentor diharuskan untuk memiliki kemantapan fikroh yang tidak hanya

57 Darori, Wawancara oleh Penulis, Masjid Manarul Ilmi Surabaya, 15 Mei 2017.

58 Ibid. mencakup soal ibadah, tapi juga akidah, akhlak, sistem sosial, politik, ekonomi, sejarah, dan lain-lain; (b) seorang mentor juga harus memahami tujuan atau goal setting yang akan dicapai dari kegiatan pembinaan mentoring. Sehingga hal tersebut akan membuat mentor memiliki kriteria atau standart dalam memahamkan para komunikan. Dengan seorang mentor memahami tujuannya dan goal settingnya maka ukuran kesuksesan dakwah akhirnya lebih jelas dan terarah; (c) seorang mentor JMMI juga harus memliliki wawasan yang luas mengenai perkembangan terkini dalam dunia islam maupun yang lainnya. Sangat penting bagi para mentor untuk memiliki pengetahuan - pengetahuan mengenai hal hal yang terjadi di dunia saat ini. Alasan seorang mentor harus memiliki pengetahuan yang luas adalah karena seorang mentor akan sering dijadikan tempat bertanya bagi para komunikannya atau mahasiswa. Dengan keluasan wawasan yang dimiliki, mentor memiliki bekal untuk menjawab persoalan-persoalan tersebut.

Mentor-mentor JMMI diwajibkan untuk selalu memahami dengan baik dan benar materi-materi mentoring yang hendak disampaikan. Hal tersebut disebabkan karena mentorlah yang akan menyampaikan materi tersebut. Untuk menjamin kualitas pemahaman mentor terhadap materi-materi mentoring, JMMI melakukan tes seleksi mentor, yang menentukan apakah seorang calon mentor layak atau tidak menjadi seorang mentor. Tes seleksi yang dilakukan JMMI ITS terdiri dari beberapa macam, salah satunya adalah

\footnotetext{
59 lbid.

60 JMMI ITS, Buku Panduan., 14.
} 
tes tulis berupa tes menguji pemahaman materi ${ }^{61}$

Mentor - mentor JMMI juga harus memiliki kemampuan berkomunikasi yang baik. Hal tersebut dikarenakan seorang mentor memiliki tugas utama yakni menyampaikan atau mengkomunikasikan materi kepada komunikan. Dengan memiliki kemampuan komunikasi yang baik, seorang mentor dapat mengkomunikasikan pesan kepada komunikan dengan menarik, dan mampu membuat komunikan tetap terjaga, tidak bosan. Agar setiap mentor memiliki kemampuan berkomunikasi yang baik, pihak JMMI memiliki sebuah tes seleksi mentor berupa tes wawancara dan simulasi komunikasi. ${ }^{62}$ Selain itu seorang mentor JMMI juga harus memiliki kemampuan membaca Alquran dengan baik dan benar. ${ }^{63}$ Alasan perlunya seorang mentor memiliki kemampuan membaca Alquran dengan baik dan benar ialah dikarenakan seorang mentor JMMI juga memiliki tugas mengajari mahasiswa baru membaca Alquran dengan baik dan benar. Sehingga bila mentornya tidak dapat membaca Alquran dengan baik dan benar serta tidak memahami hukumhukum bacaan dengan baik, maka para mahasiswa atau komunikan akan akan menilai bahwa mentornya tidak kredibel.

Mentor-mentor JMMI juga harus mampu menjadi sahabat bagi mahasiswamahasiswa binaannya dan mentoringnya. Salah satu yang membuat komunikan tertarik dengan mentor adalah ketika sang mentor mampu menjadi seorang kakak yang menjadi sahabat. Hal tersebut seperti penjelasan Darori, "Kalo menarik, mungkin

61 Darori, Wawancara oleh Penulis, Masjid Manarul Ilmi Surabaya, 15 Mei 2017.

62 Ibid. lebih bersahabat, kalau lebih pinter kadang mente ada yang dari pesantren juga malah lebih bagus. Kadang kita diskusi tapi lebih bersahabat gitu, ..."

Sehingga seorang mentor harus mampu menjadi seperti kakak bagi komunikan yang selalu siap membantu menyelesaikan masalah-masalah adiknya.

\section{Kesimpulan}

JMMI ITS telah melakukan pengenalan terhadap komunikan dahulu sebelum kegiatan mentoring dilakukan. Pengenalan terhadap mahasiswa baru yang berjumlah 3600 mahasiswa, dilakukan dengan cara memberikan tes tulis. Tes tulis tersebut berisi persoalan mengenai pengetahuanpengetahuan Islamiyah, contohnya seperti tauhid, ibadah, dan akhlak. ${ }^{65}$ Tes tulis tersebut diberikan kepada para mahasiswa dengan tujuan agar mentor JMMI mengetahui bagaimana tingkat pengetahuan yang dimiliki oleh para komunikan tersebut, khususnya mengenai soal tauhid, akhlak dan ibadah.

Mentor-mentor JMMI juga telah memetakan dan menentukan media yang yang hendak digunakan untuk menyampaikan pesan kepada mahasiswa atau komunikan. Menurut Direktur BPM, Darori para komunikan cenderung sungkan dan tertutup ketika menggunakan media SMS atau chatting-an. Oleh sebab itu, menurut Darori para mentor memilih menggunakan media langsung atau face to face. Mentor JMMI juga melakukan pemetaan terhadap pengetahuan bahasa atau perbendaharaan kata yang dimiliki

\footnotetext{
${ }^{63} \mathrm{Ibid}$.

64 Ibid.

$65 \mathrm{lbid}$.
} 
komunikannya. Menurut salah seorang mentor JMMI yang bernama Rifki, seorang mentor harus memiliki kemampuan menentukan bahasa yang akan digunakan sesuai dengan kondisi komunikannya, contohnya ketika komunikannya kesukaannya pergi ke warung kopi, maka bahasa yang digunakan ketika berkomunikasi tidak boleh kaku atau bahasa nonformal.

Selain itu, sebelum melakukan mentoring para mentor JMMI juga melakukan pemetaan terhadap kelompok yang diikuti oleh komunikan. Contohnya seperti apakah ketika di masa SMA, komunikan mengikuti rohis atau tidak. Mentor JMMI mendapatkan informasi mengenai kelompok yang diikuti oleh komunikan tersebut dari kuisioner atau angket yang diberikan kepada komunikan. Selain itu mentor JMMI juga mencari tahu tentang organisasi yang pernah diikuti oleh komunikan, baik itu organisasi dakwah maupun non dakwah. Informasi mengenai organisasi yang pernah diikuti komunikan tersebut juga didapatkan dari kuisioner yang diberikan oleh JMMI kepada komunikan ketika masa - masa awal sebelum mentoring. Tidak hanya itu, mentor JMMI juga harus peka terhadap kondisi dan situasi dari komunikannya sebelum mentoring berlangsung.

Dalam menyusun pesan, JMMI ITS selalu berusaha mendesain pesannya agar menarik bagi komunikan. Mentor JMMI juga selalu memilih bahasa yang sesuai dengan komunikan. Contohnya ketika menghadapi komunikan yang hobi cangkrukan di warung kopi, maka seorang mentor harus

66 Rifki, Wawancara oleh Penulis, 17 Mei 2017.

67 lbid. menggunakan bahasa yang tidak formal atau tidak kaku. Namun bila bila obyek mentoringnya merupakan orang yang memiliki pengetahuan yang luas maka mentor harus menggunakan istilah teknis. ${ }^{66}$ Pada kenyataannya di lapangan khusus untuk kaderisasi satu mentor masih diijinkan untuk memberikan materi-materi lain selain materi yang sesuai kurikulum yang telah ditetapkan. Syaratnya materi tersebut telah mendapatkan izin dari LDJ. ${ }^{67}$ Materi yang baru tersebut disesuaikan dengan situasi dan kondisi dari komunikan. Contohnya semisal waktu mentoring hendak dimulai mentor mengetahui bahwa komunikannya sedang down, akhirnya mentor tidak membahas materi sesuai kurikum tetapi membahas masalah yang dihadapi oleh komunikan tersebut. ${ }^{68}$

Metode komunikasi yang digunakan ketika mentoring adalah metode redudancy. Maksudnya adalah dalam mencetak kader yang berkepribadian Islami, khususnya soal ibadah, mentor JMMI tidak cukup melakukan perubahan dengan sekali saja, tetapi harus dilakukan secara terus menerus dan berproses. Para mentor setiap minggu akan selalu mengingatkan komunikannya mengenai perubahan ibadah yang telah dilakukannya. JMMI juga menggunakan metode canalizing. Ketika seorang komunikan memiliki pemikiran yang bertentangan terhadap materi yang diberikan, yang dilakukan oleh mentor JMMI adalah berusaha di awal - awal mentoring untuk tidak menyentuh dahulu konsep - konsep atau nilai yang bertentangan dengan komunikan ,tetapi lebih mengikuti konsep - konsep yang telah disepakati atau disetujui oleh komunikan

\footnotetext{
${ }^{68}$ Darori, Wawancara oleh Penulis, 15 Mei 2017.
} 
lebih dahulu. Media komunikasi yang dipilih dalam melakukan mentoring adalah media langsung atau face to face, dan media grup Whatsapp. Grup Whatsapp digunakan oleh mentor untuk memberikan wawasan ringan di luar materi mentoring baik berupa berita atau link website.

Mentor JMMI ITS juga diharuskan memahami materi-materi yang hendak disampaikan kepada para komunikan mentoring. Agar kualitas pemahaman mentor terhadap materi baik, JMMI selalu melakukan tes seleksi mentor, yang diujikan adalah pemahaman mentor terhadap materi. Para mentor JMMI ITS juga diwajibkan memiliki kemampuan komunikasi yang baik. Untuk menjamin hal tersebut JMMI melakukan tes seleksi dengan diberikan tes wawancara dan simulasi komunikasi. ${ }^{69}$ Selain itu, mentor mentor JMMI harus memiliki budi pekerti yang baik. Mentor JMMI harus memiliki karakter ruhiyah, utamanya dalam bentuk ibadah ilahiah. Selain itu mentor juga harus memiliki akhlak dan moral yang baik, hal tersebut disebabkan nantinya sang mentor akan selalu diperhatikan oleh para mahasiswanya, contohnya seperti rendah hati, toleran, bertanggung jawab memikul amanah. Mentor JMMI juga dilarang melakukan pacaran dan merokok dengan alasan apapun.

\section{Bibliografi}

Atian, Ahmad, Menuju Kemenangan Dakwah Kampus, cet-1, Era Intrmedia ,Solo, 2010.

Arifin, Anwar. Strategi Komunikasi: Sebuah Pengantar Ringkas. Bandung: Armico, 1984.

Cangara, Hafied. Perencanaan dan Strategi Komunikasi . Jakarta: Rajawali Pers, 2013.

J. Fiske, Cultural and Communication Studies: Sebuah Pengantar Paling Komprehensif.

(Terjemahan Yosal Iriantara dan Idi Subandy Ibrahim). Yogyakarta: Jalasutera, 2004.

JMMI ITS, Buku Panduan Bersama Lembaga Dakwah ITS. Surabaya: JMMI ITS, 2011.

Mulyana, Deddy. Ilmu Komunikasi Suatu Pengantar. Bandung: PT Remaja Rosdakarya, 2002.

Morissan. Manajemen Public Realitions: Strategi Menjadi Humas Profesional. Jakarta: Kencana, 2008.

Onong Uchjana Effendy. Ilmu Komunikasi Teori dan Praktek . Bandung: PT Remaja Rosdakarya, 2005.

Rafi'udin dan Maman Abdul Djaliel. Prinsip dan Strategi Dakwah. Bandung: CV. Pustaka Setia, 1997.

Rogers, Everett M. Diffusion of Innovations Third Edition. New York: The Free Press, 1983.

Syukir, Asmuni. Dasar-Dasar Strategi Dakwah Islam. Surabaya: Al-Ikhlas, 1983.

${ }^{69}$ Ibid. 
Lutfi Alvian Widianto

182 | Jurnal Kajian \& Pengembangan Manajemen Dakwah 